\title{
Factors influencing the impact of knowledge sharing behavior in organizations across Sultanate of Oman
}

\author{
Safa Paulu D'souza D'souza \\ Dr. Syed Zakir Ali
}

\author{
Middle East College \\ Middle East College
}

\begin{abstract}
This article is aimed at exploring factors that impact knowledge sharing behavior of employees in a small and medium scale (SME) building materials company located in Sultanate of Oman; and to extrapolate the findings over large organizations. The said SME has a problem of employees hoarding their knowledge and knowledge management is not in practiced. Through literature review, we have identified six factors that are of mutual relevance to SMEs and Large organizations. A survey has been conducted to test the practical implications of the identified factors at the selected organization. Results reveal that the factors such as (i) social media app for knowledge sharing (ii) enjoyment/satisfaction in helping others and (iii) effective utilization of free time; are the dominating factors in both SME and Large organizations. It is found that the factors (iv) rewards and (v) self-efficacy are very much significant in large organizations and are of low significance in SMEs. To strengthen the current study, the survey has to be extended to include respondents from few more SMEs and Large organizations.
\end{abstract}

\section{Introduction}

The number SME's are growing in Oman each year and it has become an important part of the economy as $60 \%$ of them provide employment in Oman but they face many challenges like financial, marketing and administrative challenges (Christina, Neelufer \& Al Amri, 2019). The research by (Edvardsson \& Durst, 2013) proves that knowledge management in the SME's can lead to employee development, innovation, increased sales, reduced losses, satisfied customers and better productivity thus proper knowledge management can aid in resolving much of these issues. There has been a lot of research that's been conducted in large organizations on employee knowledge sharing but there is limited research conducted in Oman on employee knowledge sharing in SME's thus this research attempts to bridge the gap.

\section{Literature Review}

\section{Knowledge Management}

Things are changing in the business world, its moving its focus from natural resources to knowledge where it's based on education, research, skills and development (Friedman \& Wyman, 2005) .Companies are hiring more 'minds' than 'hands' which shows the increasing importance of knowledge in companies today (Yew Wong, 2005). Knowledge management has become an economic resource that affects the life and success of a business. Companies must understand the importance of knowledge management and its effective implementation to keep up with the technological advancements, which helps in gaining an edge over its rivals (De Silva, 2019) .One of the main reasons why knowledge management is introduced in organizations, is because it brings positive influence and better performance to the organization. 


\section{Knowledge Sharing}

One must possess knowledge in order to acquire or share knowledge (Yang \& Chen, 2007). Knowledge sharing is one of the key areas of knowledge management and if there is no proper knowledge sharing practices, the organizations may not be able to grasp the full benefits of its knowledge asset (McLure Wasko \& Faraj, 2000).Knowledge sharing is crucial among the teams and between the teams for organizational value enhancement, development of skills and capabilities and to have a sustained competitive advantage [6]. In the act of knowledge sharing the actors, knowledge, organization, medium of sharing knowledge and a social environment are included.(Shin, 2004; Albino, Garavelli \& Schiuma, 1998; Lee \& Al-Hawamdeh, 2002). Knowledge sharing is key facilitator of knowledge management and improved sharing of the knowledge that is associated to work benefits individuals and organization. There are two aspects in knowledge sharing they are the supply, which is encouraging employees to share their knowledge and demand, which is the acquisition of knowledge by the employer (Li Yang \& C.T. Wu, 2007).

\section{Knowledge Sharing factors in SME's and large organizations}

Due to the benefits of knowledge management in organizations SME's are increasingly implementing knowledge management, although it was is a concept introduced and implemented in large organizations but SME's need different strategies than small organizations in implementing knowledge management at their organizations. Summarized below important success factors proposed by the author (Yew Wong, 2005) along with evidences from researches done by other researchers.

Support from top management and leadership: Top management must try to adopt a culture of open knowledge sharing in the organization as an example for their subordinates. There must be an on-going efforts and support from top management. The authors (Jamshidi et al., 2018; Kanaan, Hamdi Gharibeh \& (Moh'd Taisir) Masa'deh, 2013; de Almeida, Lesca \& Canton, 2016) have emphasized that in order to aid knowledge sharing there must be support from top management.There has been a positive link found between support from management and knowledge sharing (Hejase, 2014). The encouragements from top management was found to be a very helpful factor for knowledge sharing of ERP users also their encouragements for culture of social interaction was found to be more effective extrinsic motivation (Bany Baker \& M. Yusof, 2017). It was concluded by (Cyril Eze, Guan Gan Goh, Yih Goh \& Ling Tan, 2013) an empowering leadership, is necessary factor that need to be considered to promote knowledge sharing among employees.

Organizational Culture: It is the values, believes and norms that an organization follows, the culture that doesn't support knowledge management in an organization can become a barrier in the successful implementation of knowledge management. There are studies (Hejase, 2014) that prove that culture of the knowledge management in companies can help in successful implementation of knowledge management by making employees elicit knowledge. Organization culture was found to have a positive link with knowledge sharing behavior of employees ( Alam, Abdullah, Ishak \& Zain, 2009)

Information technology and the infrastructure of the organization: A good information technology for knowledge management is easy to use, it's standardized, suitable for the users ad their needs, fits the knowledge of the organization and the technology must be simple. Although information technology greatly helps in knowledge management organizations must not completely reply on information technology. The studies by (Kanaan, Hamdi Gharibeh \& (Moh'd Taisir) Masa'deh, 2013; de Almeida, Lesca \& Canton, 2016) indicate that having a good information and communication technology is necessary for factor for enabling employees to share knowledge. For implementation of Knowledge management it is important to develop a good infrastructure although most organizations already have a HR and IT department, it must assign a team whose position can be 


\section{Journal of Student Research}

Fourth Middle East College Student Research Conference, Muscat, Sultanate of Oman

filled by existing employees or could be hired. Large companies appoint a Chief Knowledge Officer but SME's can go for something that's suitable for them. It was found by (Bany Baker \& M. Yusof, 2017)that an effective communication was necessary factor as well as information and communication mediums and communication technology was found to have positive link with knowledge sharing by (Alam, Abdullah, Ishak \& Zain, 2009; Cyril Eze, Guan Gan Goh, Yih Goh \& Ling Tan, 2013)

Well planned strategy and purpose: It is important that all those who are involved in this must realize the purpose behind implementation of knowledge management and they must all have a common vision. There are various strategies that the organization can adopt but these strategies must be bent towards the organizational strategies where knowledge management is being implemented.

Measuring: For the organization to evaluate, compare, control and enhance their performance it must measure and understand the progress and effectiveness of knowledge management. This is important for the attainment of knowledge management objectives. Without measurement it can turn it a management fad.

Processes: Organization must have a process-based approach towards knowledge management because process comes at the center of knowledge management implementation. In order to have a structured and systematic knowledge management process proper mechanism and interventions are necessary.

Motivation and Rewards: The best infrastructure, investments and technology will lead knowledge management to failure if the employees are not happy or motivated. For this purpose it is important to make them recognize themselves as the "intellectual property" of the company by giving the feedback of the knowledge they shared this will show the importance of their knowledge in the organization researchers (Hejase, 2014; Yew Wong, 2005; de Almeida, Lesca \& Canton, 2016). (Razmerita, Kirchner \& Nielsen, 2016) found that employees share their knowledge because it's important for the organization and it was the dominant factor in their results. They also found that employees look for a social reward for sharing their knowledge .Companies can use monetary as well as non-monetary rewards for motivation .Reward was found by (Kanaan, Hamdi Gharibeh \& (Moh'd Taisir) Masa'deh, 2013; Cyril Eze, Guan Gan Goh, Yih Goh \& Ling Tan, 2013) to be an important enabler of knowledge sharing in employees. ). Researchers (Alam, Abdullah, Ishak \& Zain, 2009) concluded that more the rewards higher will be the knowledge sharing behaviors in employees.

Resources: Human resource, free time and financial resource are the three important resources required for the implementation of knowledge management.SME's deal with limited resources so their judicious allocation and management of resources is crucial. Knowledge sharing facilities must be provided by the organizations for formal as well as informal conversations for knowledge sharing along with free time (Staplehurst \& Ragsdell, 2010). The study by (Razmerita, Kirchner \& Nielsen, 2016) indicates that free time is a facilitator for knowledge sharing in employees.

Training: In order to bring about a common language and understanding.Training must be done. Training must be also given to the employees on their new roles and IT solutions.

Managing Human resource: Humans are an important part of knowledge management as it's by them knowledge originates for this the right employees must be hired who suit the knowledge management culture.

Willingness to help others: Employees always don't share their knowledge for any rewards, many of the times they do so simply because they like to share their knowledge due to their willingness to help others, this is supported by the studies by (Kanaan, Hamdi Gharibeh \& (Moh'd Taisir) Masa'deh, 2013). . (Razmerita, Kirchner \& Nielsen, 2016) who found that employees like helping 


\section{Journal of Student Research}

others was a factor that had relationship with knowledge sharing of the employees which is consistent with the findings of researchers (Islam, Jantan, Khan, Rahman \& Monshi, 2018;Irma Susanty \& Charles Wood, 2011)

Self-Efficacy: For the employees to voluntarily share knowledge they must have the sense of selfefficacy that their experience and knowledge is valuable for the organization (Staplehurst \& Ragsdell, 2010). In the model proposed by (Chau, 2018) self-efficacy and employee attitude were important factors for knowledge sharing. Employees share knowledge if they feel that their knowledge is useful for the organization (Razmerita, Kirchner \& Nielsen, 2016) and it was found to have a strong relationship with knowledge sharing by (Akram, Naeem Shahid, Iqbal \& Rabia Akram, 2019).

There are two less explored factors that are found to be a driving factor in knowledge sharing behavior that is the status of the employees and their roles (Park, Chae \& Choi, 2017). Trust is another less explored factor which had a positive link with knowledge sharing (Cyril Eze, Guan Gan Goh, Yih Goh \& Ling Tan, 2013; Hejase, 2014)

\section{Factors Identified from the literature}

Based on the literature review, the following consistent six factors that influence employee knowledge sharing behavior were identified which were consistent throughout the researches they are: Social media app ICT, Top management support, free time, rewards enjoyment in helping other and self-efficacy. It was found that Rewards and self-efficacy were seen frequently to be high in large organizations than in SME's.

\begin{tabular}{|c|c|c|}
\hline Author & Knowledge sharing factors & SME / Large Organization \\
\hline $\begin{array}{l}\text { (Kanaan, Hamdi Gharibeh \& (Moh'd } \\
\text { Taisir) Masa'deh, 2013) }\end{array}$ & $\begin{array}{l}\text { Support from top management support, } \\
\text { ICT (information and communication } \\
\text { technology), rewards and willing to help } \\
\text { others }\end{array}$ & Large organization \\
\hline (Jamshidi et al., 2018) & Top management support & Large Organization \\
\hline (Hejase, 2014) & $\begin{array}{l}\text { support from management, trust, the } \\
\text { organizational culture and intellectual } \\
\text { possession }\end{array}$ & Large Organization \\
\hline (de Almeida, Lesca \& Canton, 2016) & $\begin{array}{l}\text { Support from top management, } \\
\text { information system support and } \\
\text { information feed-back }\end{array}$ & Large organization \\
\hline (Park, Chae \& Choi, 2017) & status and roles of the employees & Large Organization \\
\hline (Bany Baker \& M. Yusof, 2017). & $\begin{array}{l}\text { top management support, culture of } \\
\text { social interaction effective } \\
\text { communication and communication } \\
\text { mediums }\end{array}$ & SME \\
\hline (Staplehurst \& Ragsdell, 2010). & $\begin{array}{l}\text { self-efficacy free time facilities for } \\
\text { formal as well as informal conversations }\end{array}$ & SME \\
\hline (Alam, Abdullah, Ishak \& Zain, 2009) & $\begin{array}{l}\text { organizational culture, trust and } \\
\text { communication technology }\end{array}$ & SME \\
\hline $\begin{array}{l}\text { (Cyril Eze, Guan Gan Goh, Yih Goh \& } \\
\text { Ling Tan, 2013) }\end{array}$ & $\begin{array}{l}\text { knowledge sharing technology } \\
\text { empowering leadership, motivation, } \\
\text { trust and a reward system }\end{array}$ & SME \\
\hline (Razmerita, Kirchner \& Nielsen, 2016) & $\begin{array}{l}\text { Importance of the knowledge for the } \\
\text { organization, self-efficacy Employees } \\
\text { like helping others recognition of } \\
\text { knowledge sharing. social rewards and } \\
\text { free time. }\end{array}$ & Large organization \\
\hline \multirow{2}{*}{$\begin{array}{l}\text { (Islam, Jantan, Khan, Rahman \& } \\
\text { Monshi, 2018) }\end{array}$} & Employees like helping others & Both \\
\hline & $\begin{array}{l}\text { Feel happy to share their knowledge } \\
\text { and rewards, self-efficacy, }\end{array}$ & \\
\hline
\end{tabular}




\begin{tabular}{|l|l|l|}
\hline (Chau, 2018) & $\begin{array}{l}\text { Trust between individuals, commitment } \\
\text { towards organization, self -efficacy and } \\
\text { attitude. }\end{array}$ & Both \\
\hline (Yew Wong, 2005) & $\begin{array}{l}\text { Support from top management, } \\
\text { leadership, culture of organization, } \\
\text { Rewards, processes, infrastructure, } \\
\text { resources, training, HR management }\end{array}$ & SME \\
\hline (Irma Susanty \& Charles Wood, 2011) & $\begin{array}{l}\text { Intrinsic and extrinsic: Rewards and } \\
\text { self-efficacy }\end{array}$ & Large \\
\hline
\end{tabular}

Table 1. Identified knowledge sharing factors from large and small organizations.

\section{Research design and Objectives}

First through interview method the problem at the selected SME is identified, which was employee hoarding knowledge in the company. Next literature review was done with published journal and conference proceedings articles for identifying the factors that influence the knowledge sharing in SME's and Large Organizations. These identified factors were tested with the help of a questionnaire method which consisted of six parts each with questions regarding the six identified factors from the literature. The data is analyzed by narrative analysis and presented in the form of a table. Finally results are discussed with recommendations. Quantitative and Qualitative methods are undertaken in this research.

\section{Objective 1}

To examine the association of knowledge sharing factors, self-efficacy, enjoyment in helping others, social media app (Information and communication tool), monetary reward, support from top management and free time with employee knowledge sharing behavior.

\section{Objective 2}

To examine if the knowledge sharing factors that were significant in large organization also influence knowledge sharing in small organization.

\section{Research Findings}

\begin{tabular}{|c|c|c|c|}
\hline Survey Questions & Yes & No & Maybe \\
\hline \multicolumn{4}{|c|}{ Self-Efficacy } \\
\hline $\begin{array}{l}\text { Do you think most of } \\
\text { the other employees } \\
\text { cannot provide more } \\
\text { valuable ideas, skills an } \\
\text { experiences as you can? }\end{array}$ & $47.1 \%$ & $52.9 \%$ & $0 \%$ \\
\hline $\begin{array}{l}\text { Do you believe that you } \\
\text { possess ideas, } \\
\text { experiences and skills } \\
\text { that are beneficial for } \\
\text { your organization? }\end{array}$ & $52.9 \%$ & $5.9 \%$ & $41.2 \%$ \\
\hline \begin{tabular}{|l|} 
If you feel that your \\
ideas, experiences and \\
skills are not important, \\
would you share it with \\
your co-workers or \\
company as a whole?
\end{tabular} & $47.1 \%$ & $52.9 \%$ & \\
\hline \multicolumn{4}{|c|}{ Enjoyment in helping other } \\
\hline $\begin{array}{l}\text { Do you like to share } \\
\text { your experiences, skills } \\
\text { and ideas with your co- }\end{array}$ & $100 \%$ & $0 \%$ & $0 \%$ \\
\hline
\end{tabular}




\section{Journal of Student Research}

Fourth Middle East College Student Research Conference, Muscat, Sultanate of Oman

workers?

Does sharing your experiences, skills and

ideas with your co-

workers make you

happy?

\begin{tabular}{|c|c|c|c|c|}
\hline \multicolumn{5}{|c|}{ Rewards } \\
\hline $\begin{array}{l}\text { Do you think your } \\
\text { company should give } \\
\text { higher salary for } \\
\text { sharing your ideas, } \\
\text { experience, and skills } \\
\text { with your co-workers? }\end{array}$ & $41.2 \%$ & \multicolumn{2}{|c|}{$58.8 \%$} & $0 \%$ \\
\hline \begin{tabular}{|l|} 
Do you think your \\
company should give \\
promotions for sharing \\
your ideas, experience, \\
and skills with your co- \\
workers?
\end{tabular} & $58.8 \%$ & \multicolumn{2}{|c|}{$41.2 \%$} & $0 \%$ \\
\hline \multicolumn{5}{|c|}{ Information and communication Technology } \\
\hline $\begin{array}{l}\text { Does your company use } \\
\text { any information and } \\
\text { communication } \\
\text { technology (ICT)? }\end{array}$ & \multicolumn{2}{|c|}{$76.5 \%$} & $23.5 \%$ & \\
\hline \begin{tabular}{|l|} 
Do you think you can \\
easily share your ideas, \\
experiences and skills \\
with the help of a social \\
media app like whats \\
app?
\end{tabular} & \multicolumn{2}{|c|}{$94.1 \%$} & $5.9 \%$ & \\
\hline $\begin{array}{l}\text { Do you think it's better } \\
\text { to use a social media } \\
\text { app rather than } \\
\text { meeting face to face to } \\
\text { share your ideas, } \\
\text { experiences and skills } \\
\text { with your co-workers? }\end{array}$ & \multicolumn{2}{|c|}{$41.2 \%$} & 52.9 & Both are okay 5.9 \\
\hline \multicolumn{3}{|c|}{ Top Management support } & & \\
\hline \multicolumn{2}{|c|}{ Survey Questions } & Responses & & \\
\hline \multicolumn{2}{|c|}{$\begin{array}{c}\text { I will share my skills, ideas and experiences only } \\
\text { if the top management values it }\end{array}$} & $70.6 \%$ & & \\
\hline \multicolumn{2}{|c|}{$\begin{array}{c}\text { I will NOT share my skills, ideas and experiences } \\
\text { if the top management DOES NOT value it. }\end{array}$} & $11.8 \%$ & & \\
\hline \multicolumn{2}{|c|}{$\begin{array}{c}\text { I will NOT share my skills, ideas and experiences } \\
\text { EVEN IF the top management values it. }\end{array}$} & $5.9 \%$ & & \\
\hline \multicolumn{2}{|c|}{$\begin{array}{c}\text { I will share my skills, ideas and experiences only } \\
\text { if the top management shares their skill, ideas } \\
\text { and experiences. }\end{array}$} & $17.6 \%$ & & \\
\hline \multicolumn{2}{|c|}{$\begin{array}{c}\text { I will share, no matter what top management } \\
\text { thinks about it. }\end{array}$} & $5.9 \%$ & & \\
\hline \multicolumn{4}{|c|}{ Resources } & \\
\hline \multicolumn{5}{|c|}{ Which of the below mentioned scenario is true according to you? } \\
\hline $\begin{array}{l}\text { I will share my skills, } \\
\text { ideas and experiences } \\
\text { with my co-workers } \\
\text { only if I have free time }\end{array}$ & \multicolumn{2}{|c|}{$88.2 \%$} & & \\
\hline $\begin{array}{l}\text { I will not share my } \\
\text { skills, ideas and } \\
\text { experiences with my co- } \\
\text { workers even if I have } \\
\text { free time }\end{array}$ & \multicolumn{2}{|c|}{$11.8 \%$} & & \\
\hline
\end{tabular}

Table 2. following table displays the research findings 


\section{Findings and Recommendations}

\section{Objective 1:}

The findings show that the three factors that is Social media app, free time and enjoyment in helping others impact the knowledge sharing behavior positively.

All of the employees accepted that they will share knowledge because it makes them feel good and they like helping people. This is a good indicator that for adopting knowledge management at the selected organization as knowledge management is not possible if employees are not willing to share their knowledge.

$94 \%$ of them say that a social media app can aid them in sharing their knowledge better is notable since a large number of employees agreed to it the organization must plan to use social media app for knowledge sharing. The various requirements of knowledge sharing can be supported by the a social media app thus making it a good medium to share knowledge (Panahi, Watson \& Partridge, 2012)

Most employees agreed that if free time was given to them they would share their knowledge and they would do so only if free time is available to them; this indicates that for the purpose of eliciting employee knowledge the organization must conduct brainstorming and other knowledge sharing sessions. As researcher (Panahi, Watson \& Partridge, 2012) suggests that even story telling is a great way to elicit employees tacit knowledge.

Support from top management was a factor that was found to influence the most after the above mentioned factors, thus it is important that the managers at the top level must be an example for their subordinates to share knowledge. It is important that employees know the value of their knowledge for the organization because most employees agreed in the survey that they would share their knowledge only if the top management values it.

Almost half of the respondents were found to be unsure if the knowledge they possess is beneficial for the organization and most of them agree that if their knowledge is not important they wouldn't share it the organization this indicates that employees must be made aware of the worth of their knowledge for the organization. This could be done by using giving feedbacks as the researcher (de Almeida, Lesca \& Canton, 2016 says that organizations must give feedback regarding how useful their information is for the organization

The responses about the rewards show that half of the employee wants a monetary reward and other half non-monetary rewards, this could be because of what the research mentions (Hanif, Khalid \& Khan, 2013) about maslow's hierarchy with regards to employees that having a low income will tend to make employees have psychological insecurities. Thus these employee will choose a monetary reward and the ones with higher salaries will choose a non-monetary reward.

\section{Objective 2:}

It was found that Rewards and self-efficacy were not as high as it is in large organizations. In the Small organization that was examined factors like Social media app, free time and enjoyment in helping others was high

These findings can be an answer to the question the selected organization is facing with employee knowledge hoarding. 


\section{Limitations}

The main limitation of this research is that the respondents were taken from only one organization and a very small sample size was taken. Future research can be done by taking a larger sample from multiple organizations.

\section{References}

Christina, B., Neelufer, A., \& Al Amri, S. (2019). CHALLENGES AND BARRIERS ENCOUNTERED BY THE SMES OWNERS IN MUSCAT. International Journal Of Small Business And Entrepreneurship Research, 2(3), 1-13. Retrieved from http://www.eajournals.org/wpcontent/uploads/Challenges-and-Barriers-Encountered-By-the-SMES-Owners-in-Muscat.pdf

Edvardsson, I., \& Durst, S. (2013). The Benefits of Knowledge Management in Small and Mediumsized Enterprises. Procedia - Social And Behavioral Sciences, 81, 351-354. doi:

10.1016/j.sbspro.2013.06.441

De Silva, M. (2019). An Empirical Review: Knowledge Management \& Its Implications in the Contemporary Business Context. International Journal Of Research In Business Studies And Management, 6(2), 39-44. Retrieved from https://www.ijrbsm.org/papers/v6-i2/4.pdf

Friedman, T., \& Wyman, O. (2005). The world is flat (1st ed.). New York: Audio Renaissance.

McLure Wasko, M., \& Faraj, S. (2000). "It is what one does": why people participate and help others in electronic communities of practice. The Journal Of Strategic Information Systems, 9(2-3), 155-173. doi: 10.1016/s0963-8687(00)00045-7

Rašula, J., Bosilj Vukšić, V., \& Indihar Štemberger, M. (2019). THE IMPACT OF KNOWLEDGE MANAGEMENT ON ORGANISATIONAL PERFORMANCE. Economic And Business Review, 14(2), 147-168. Retrieved from https://pdfs.semanticscholar.org/8310/4e499b8234d99a29531df29b6aff9320e664.pdf

RENZL, B. (2008). Trust in management and knowledge sharing: The mediating effects of fear and knowledge documentation. Omega, 36(2), 206-220. doi: 10.1016/j.omega.2006.06.005

Yang, C., \& Chen, L. (2007). Can organizational knowledge capabilities affect knowledge sharing behavior?. Journal Of Information Science, 33(1), 95-109. doi: 10.1177/0165551506068135

Yew Wong, K. (2005). Critical success factors for implementing knowledge management in small and medium enterprises. Industrial Management \& Data Systems, 105(3), 261-279. doi: $10.1108 / 02635570510590101$

Shin, M. (2004). A framework for evaluating economics of knowledge management systems. Information \& Management, 42(1), 179-196. doi: 10.1016/j.im.2003.06.006

Albino, V., Garavelli, A., \& Schiuma, G. (1998). Knowledge transfer and inter-firm relationships in industrial districts: the role of the leader firm. Technovation, 19(1), 53-63. doi:

10.1016/s0166-4972(98)00078-9

Lee, C., \& Al-Hawamdeh, S. (2002). Factors Impacting Knowledge Sharing. Journal Of Information \& Knowledge Management, 01(01), 49-56. doi: 10.1142/s0219649202000169

Li Yang, H., \& C.T. Wu, T. (2007). Knowledge sharing in an organization. Technological Forecasting \& Social Change, 75(8), 1128-1156. doi: 10.1016/j.techfore.2007.11.008 


\section{Journal of Student Research}

Fourth Middle East College Student Research Conference, Muscat, Sultanate of Oman

Yew Wong, K. (2005). Critical success factors for implementing knowledge management in small and medium enterprises. Industrial Management \& Data Systems, 105(3), 261-279. doi:

$10.1108 / 02635570510590101$

Jamshidi, E., Nedjat, S., Nedjat, S., Nikooee, S., Rostamigooran, N., \& Majdzadeh, R. (2018). How to utilize tacit knowledge in health organizations: An Iranian perspective. Medical Journal Of The Islamic Republic Of Iran, 678-685. doi: 10.14196/mjiri.32.116

Kanaan, R., Hamdi Gharibeh, A., \& (Moh'd Taisir) Masa'deh, R. (2013). "The Impact Of Knowledge Sharing Enablers On Knowledge Sharing Capability: An Empirical Study On Jordanian Telecommunication Firms". European Scientific Journal, 9(22), 237-258. Retrieved from https://ww w.researchgate.net/publication/260082331_THE_IMPACT_OF_KNOWLEDGE_SHARING_ENABLER S_ON_KNOWLEDGE_SHARING_CAPABILITY_AN_EMPIRICAL_STUDY_ON_JORDANIAN_TELECOM MUNICATION_FIRMS

de Almeida, F., Lesca, H., \& Canton, A. (2016). Intrinsic motivation for knowledge sharing competitive intelligence process in a telecom company. Journal Of Knowledge Management, 20(6), 1282-1301. doi: 10.1108/jkm-02-2016-0083

Hejase, H. (2014). Knowledge Sharing: Assessment of Factors Affecting Employee' Motivation and Behavior in the Lebanese Organizations. Journal Of Scientific Research And Reports, 3(12), 1549-1593. doi: 10.9734/jsrr/2014/8107

Park, J., Chae, H., \& Choi, J. (2017). The need for status as a hidden motive of knowledge-sharing behavior: An application of costly signaling theory. Human Performance, 30(1), 21-37. doi: 10.1080/08959285.2016.1263636

Bany Baker, M., \& M. Yusof, Z. (2017). "Factors Influencing Knowledge Sharing In Enterprise Resource Planning System Usage In Small And Medium Enterprises. Journal Of Theoretical And Applied Information Technology, 95(8), 1693-1702. Retrieved from https://www.researchgate.net/p ublication/319502236_Factors_Influencing_Knowledge_Sharing_in_Enterprise_Resource_Planning_ System_Usage_in_Small_and_Medium_Enterprises

Staplehurst, J., \& Ragsdell,, G. (2010). Knowledge Sharing in SMEs: A Comparison of Two Case Study Organisations. Journal Of Knowledge Management Practice, 11(1). Retrieved from http://www.tlainc.com/articl211.htm

Alam, S., Abdullah, Z., Ishak, N., \& Zain, Z. (2009). Assessing Knowledge Sharing Behaviour among Employees in SMEs: An Empirical Study. International Business Research, 2(2). doi:

10.5539/ibr.v2n2p115

Cyril Eze, U., Guan Gan Goh, G., Yih Goh, C., \& Ling Tan, T. (2013). Perspectives of SMEs on knowledge sharing. VINE, 43(2), 210-236. doi: 10.1108/03055721311329963

Razmerita, L., Kirchner, K., \& Nielsen, P. (2016). What factors influence knowledge sharing in organizations? A social dilemma perspective of social media communication. Journal Of Knowledge Management, 20(6), 1225-1246. doi: 10.1108/jkm-03-2016-0112

Chau, S. (2018). Enhancing Organizational Performance by Knowledge Sharing. Journal Of Business Theory And Practice, 6(2), 154. doi: 10.22158/jbtp.v6n2p154

Akram, Z., Naeem Shahid, M., Iqbal, Z., \& Rabia Akram, H. (2019). HOW SELF-EFFICACY INFLUENCES KNOWLEDGE SHARING AND ORGANIZATIONAL CITIZENSHIP BEHAVIOR: A SOCIAL APPROACH FORM EMPLOYEES OF PHARMACEUTICAL COMPANIES. Indo American Journal Of Pharmaceutical Science, 6(1), 643-651. Retrieved from 


\section{Journal of Student Research}

Fourth Middle East College Student Research Conference, Muscat, Sultanate of Oman

http://file://C:/Users/Hp/Downloads/109.\%20IAJP\%20(2).pdf

Islam, M., Jantan, A., Khan, A., Rahman, M., \& Monshi, O. (2018). Impact of motivational factors on knowledge sharing behaviour of managers in Ready Made Garments (RMG) Industry of Bangladesh. Journal Of Business \& Retail Management Research, 13(01). doi: 10.24052/jbrmr/v13is01/art-18

Irma Susanty, A., \& Charles Wood, D. (2011). THE MOTIVATION TO SHARE KNOWLEDGE OF THE EMPLOYEES IN THE TELECOMMUNICATION SERVICE PROVIDERS IN INDONESIA. In International Conference on Social Science and Humanity. Singapore: IACSIT Press. Retrieved from http://www.ipedr.com/vol5/no2/36-H10117.pdf

Panahi, S., Watson, J., \& Partridge, H. (2012). Social Media and Tacit Knowledge Sharing: Developing a Conceptual Model. In World Academy of Science, Engineering and Technology (pp. 1095-1102). Paris. Retrieved from http://esearchgate.net/publication/264354686_Social_Media_and _Tacit_Knowledge_Sharing_Developing_a_Conceptual_Model

Hanif, A., Khalid, W., \& Khan, T. (2013). Relating Maslow's Hierarchy of Needs with Employee Turnover and Retention: Case Study of Local Telco. International Journal Of Human Resource Studies, 3(2), 51. doi: 10.5296/ijhrs.v3i2.3864 